\title{
BODY MASS INDEX, WAIST-HIP RATIO AND FASTING BLOOD GLUCOSE LEVELS AMONGST UNIVERSITY STUDENTS
}

\author{
Rury Tiara Oktariza ${ }^{2}$, Viskasari P Kalanjati ${ }^{1 *}$, Ni Wajan Tirthaningsih ${ }^{1}$ \\ ${ }^{1}$ Department of Anatomy and Histology, Faculty of Medicine, Universitas Airlangga, Surabaya, Indonesia, \\ ${ }^{2}$ Faculty of Medicine, Universitas Airlangga, Surabaya, Indonesia
}

\section{ABSTRACT}

Overweight and obesity have been correlated to the higher risk for developing metabolic diseases in later life, such as DM type 2. This study reseached the body mass index (BMI), the waist to hip ratio (WHR) and the fasting blood glucose levels (FBG) in the seemingly healthy university students to comprehend these variables amongst the youth in Indonesia in 2019. The BMI and WHR of 150 male and female students aged 18-22 years old of the IIKBW, Kediri were measured by standardised anthropometry. The FBG was measured after 8 hours-minimum of fasting from the capillary blood drop using glucometer. Data was then analysed using SPSS 17 with level of significance of $P<0.05$. According to Asia-Pacific BMI classification, students were $30.7 \%$ obese with males significantly higher than females $(P=0.016), 18 \%$ overweight (significantly higher in females, $P=0.04$ ), 36\% normal and $15.3 \%$ underweight. When compared between genders, the WHR was significantly higher in males $(P<0.001)$; while there were no significant differences in $F B G(P=0.6) .4$ males and 5 females with $F B G>=100$ $\mathrm{mg} / \mathrm{dl}$, whereas others were within normal limits. There were positive significant correlations between BMI and WHR in males and females $(r=0.777, P<0.001 ; r=0.54, P<0.001$, respectively). There was a significant positive correlation between the $B M I$ and $F B G$ with $r=0.217, P=0.008$; and between the WHR and $F B G$ with $r=0.21, P=0.01$ amongst all students. In this study, male students have significantly higher BMI and WHR than females. Higher FBG was well observed in students with either higher BMI or WHR.

Keywords: BMI; diabetes mellitus; obesity

\section{ABSTRAK}

Obesitas dan kelebihan berat badan berkorelasi dengan tingginya resiko mengidap berbagai penyakit metabolik di kemudian hari, termasuk DM tipe 2. Penelitian ini bertujuan menganalisis hubungan indeks massa tubuh (IMT), rasio lingkar pinggangpanggul (WHR) dan kadar glukosa darah puasa (GDP) pada mahasiswa laki-laki dan perempuan usia 18-22 tahun di IIKBW, Kediri tahun 2019. IMT dan WHR dari 150 mahasiswa dinilai dengan metode antropometri terstandarisasi. GDP dari darah kapiler diukur menggunakan glukometer minimal 8 jam pasca puasa. Data dianalisis dengan menggunakan SPSS 17 dengan tingkat signifikansi P <0,05. Berdasarkan klasifikasi IMT Asia Pasifik, 30,7\% subjek mengalami obesitas (IMT laki-laki lebih besar dibandingkan perempuan; $P=0,016$ ), $18 \%$ gemuk (IMT lebih besar pada perempuan, $P=0,04$ ), 36\% normal dan 15,3\% kurus. WHR lebih besar pada laki-laki $(P<0,001)$ meskipun tidak terdapat perbedaan bermakna antara GDP laki-laki dan perempuan $(P=0,6)$. Didapatkan 4 laki-laki dan 5 perempuan memiliki GDP $>=100 \mathrm{mg} / \mathrm{dl}$. Terdapat korelasi yang bermakna antara IMT dan WHR pada laki-laki dan perempuan $(r=0,777, P<0,001 ; r=0,54, P<0,001)$. Terdapat korelasi positif dan bermakna antara IMT dan GDP dengan $r=0,217, P=0,008$; dan antara WHR dan GDP dengan $r=0,21, P=0,01$ dari seluruh mahasiswa. Pada penelitian ini, IMT dan WHR mahasiswa laki-laki lebih besar secara bermakna daripada perempuan. GDP yang tinggi cenderung ditemukan pada mahasiswa dengan IMT atau WHR yang lebih besar.

Kata kunci: IMT; diabetes mellitus; obesitas

Correspondence: Viskasari P Kalanjati, Department of Anatomy and Histology, Faculty of Medicine, Universitas Airlangga, Surabaya, Indonesia. E-mail: viskasari-p-k@fk.unair.ac.id

pISSN:2355-8393 • eISSN: 2599-056x • doi: 10.20473/fmi.v57i1.14661

- Fol Med Indones. 2020;57:53-57 • Received 31 Jul 2019 • Accepted 16 Jan 2020

- Open access under CC-BY-NC-SA license • Available at https://e-journal.unair.ac.id/FMI/

\section{INTRODUCTION}

The prevalence of overweight and obesity are increasing thus becoming a global health concern (Mehdad et al 2012, Poobalan \& Aucott 2016). These conditions have also been reported amongst the youth, which might increase the risk to suffer various metabolic diseases in later life (Poobalan \& Aucott 2016). Several metabolic diseases correlated to obesity i.e. type-2 diabetes mellitus (T2DM) (Stroud et al 2015, Portero et al 2014). 
Early identification of overweight and obesity in the young adults is warranted. World Health Organisation (WHO) has recommended the measurement of body mass index (BMI) as the simplest way for defining obesity (Mishra et al 2014). However, the BMI is an indirect measurement for body fat because the fat mass and the lean body mass components are not differentiated, as such in the measurement of the waisthip ratio (WHR). WHR that is more accurate in measuring body fat distribution, can predict visceral fat/central obesity (apple-shaped or pear-shaped obesity), after adjusting to the BMI (Doustjalal et al 2016, Gadekar et al 2018, Fu et al 2015). In this study, we analysed the BMI and WHR in the seemingly healthy male and female university students and correlated these variables to the fasting blood glucose levels (FBG) as one indicator of prediabetes.

\section{MATERIALS AND METHODS}

The study was conducted amongst 74 male and 76 female students of the Faculty of Dentistry, Institut Ilmu Kesehatan Bhakti Wiyata (IIKBW), Kediri, East Java, Indonesia aged 18-22 years old. Ethical clearance was obtained from the Research and Ethical Committee of Universitas Airlangga, Surabaya, Indonesia. After informed consent and information for consent were signed, all subjects were fasting overnight from 10.00 pm until the study began at approximately $07.00 \mathrm{am}$ in the next morning. The weight, height, waist circumference and hip circumference were measured using standard anthropometry. Body weight was measured to the nearest $0.1 \mathrm{~kg}$ using Omron HN289 (Omron, Japan) digital weighing scale placed on a firm, flat ground with subjects wearing light clothing and no shoes; belts and other accessories were removed and pockets emptied. Height was measured to the nearest $0.1 \mathrm{~cm}$ using a wall-mounted tape measure (GEA, Indonesia) with the subjects standing erect, barefoot, heels together and looking straight ahead in the Frankfurt plane.

The BMI was calculated as weight in kilograms divided by height squared in metres. Subjects with BMI of less than $18.5 \mathrm{~kg} / \mathrm{m} 2$ were classified as underweight, 18.5 $22.9 \mathrm{~kg} / \mathrm{m} 2$ were classified as normal weight, $23.0-24.9$ $\mathrm{kg} / \mathrm{m} 2$ were classified as overweight, $25.0-29.9 \mathrm{~kg} / \mathrm{m} 2$ were classified as obese I and BMI greater than or equal to $30 \mathrm{~kg} / \mathrm{m} 2$ were defined as obese II (WHO 2000). Waist circumference and hip circumference (both in $\mathrm{cm}$ ) was measured using the tape measure SECA 201 (SECA, Germany) according to WHO guidelines (WHO 2011). Waist circumference was measured to the nearest $0.1 \mathrm{~cm}$ in standing position at the midpoint between the lower margin of the last palpable rib and the top of the iliac crest and at the end of normal expiration. Hip circumference was measured to the nearest $0.1 \mathrm{~cm}$ at the widest diameter around the hip and having the greater trochanter as the landmark. The WHR was calculated as waist circumference divided by the hip circumference. The waist-hip ratio cutt-off point for Asian was 0.90 and 0.80 for male and female, respectively. Apple-shaped obesity was defined as high BMI (BMI ? $23 \mathrm{~kg} / \mathrm{m} 2$ ) with high WHR (WHR > 0.90 for male and $>0.80$ for female), while pear-shaped obesity was defined as high BMI (BMI ? $23 \mathrm{~kg} / \mathrm{m} 2$ ) with low WHR (WHR $<0.90$ for male and $<0.80$ for female) (Fu et al 2015, WHO 2000, WHO 2011). Capillary blood sample was taken to measure the FBG using Accu-Chek Active ${ }^{\circledR}$ glucometer (Germany); after the index or middle finger had been cleaned with alcohol swab.

The finger site was then dried and finger-prick done with single-use lancet or a lancing device to draw blood for each subject. Fasting blood glucose (FBG) was classified according to the recommendation of Perkumpulan Endokrinologi Indonesia (PERKENI) (2015); FBG <100 $\mathrm{mg} / \mathrm{dL}$ is normal fasting glucose; FBG $100-125 \mathrm{mg} / \mathrm{dL}$ was prediabetes and FBG ? 126 $\mathrm{mg} / \mathrm{dL}$ was provisional diagnosis of diabetes. According to American Diabetes Association (2005), prediabetes is similar to impaired fasting glucose (PERKENI 2015, ADA 2005). The data were analyzed using SPSS 17.0 for Windows. For difference of variables in male and female students. t-test or Mann-Whitney $U$ test for independent samples were used to compare mean scores, and the Chi-square was used to compare frequencies. Pearson correlations of BMI, WHR and FBG of the subjects were assessed. $\mathrm{P}<0.05$ was regarded as significant.

\section{RESULTS}

Data on various anthropological parameters and fasting blood glucose were given in Table 1. According to Asia-Pacific BMI classification, students were $30.7 \%$ obese with males significantly higher than females $(\mathrm{P}=$ 0.016 ), $18 \%$ overweight (significantly more in females, $\mathrm{P}=0.04), 36 \%$ normal and $15.3 \%$ underweight. However, the overall BMI showed no significant differences between males and females $(\mathrm{P}=0.41)$. The apple-shaped obesity was higher in females (18.4\%) than in males (14.9\%), whilepear-shaped obesity was higher in males (36.5\%) than in females $(27.6 \%)$ although not significantly different $(\mathrm{P}>0.05)$. When compared between genders, the WHR was significantly higher in males ( $\mathrm{P}<0.001)$; while there was no significance in FBG $(P=0.6)$.

Table 1. Anthropometry parameters and fasting blood glucose of males and females 


\begin{tabular}{lllll}
\hline Variables & All & $\begin{array}{l}\text { Males } \\
(\mathrm{n}=74)\end{array}$ & $\begin{array}{l}\text { Females } \\
(\mathrm{n}=76)\end{array}$ & $p$ value \\
\hline Weight $(\mathrm{kg})(\mu(\mathrm{SD}))$ & $62.3(14.9)$ & $67.9(15.9)$ & $56.7(11.5)$ & $<0.001$ \\
Height $(\mathrm{cm})(\mu(\mathrm{SD}))$ & $162.1(8.3)$ & $168.2(5.8)$ & $156.1(5.6)$ & $<0.001$ \\
BMI $(\mathrm{kg} / \mathrm{m} 2)(\mu(\mathrm{SD}))$ & $23.6(4.8)$ & $23.9(5.1)$ & $23.3(4.5)$ & 0.411 \\
$\quad$ Underweight $(\mathrm{n}(\%))$ & $23(15.3)$ & $12(16.2)$ & $11(14.5)$ & 0.945 \\
Normal $(\mathrm{n}(\%))$ & $54(36)$ & $24(32.4)$ & $30(39.5)$ & 0.467 \\
Overweight (n (\%)) & $27(18)$ & $8(10.8)$ & $19(25)$ & 0.040 \\
Obese I \& II (n (\%)) & $46(30.7)$ & $30(40.5)$ & $16(21)$ & 0.016 \\
BMI $\geq 23 \mathrm{~kg} / \mathrm{m}^{2}(\mathrm{n}(\%))$ & $73(48.7)$ & $38(51.4)$ & $35(46.1)$ & 0.627 \\
WC $(\mathrm{cm})(\mu(\mathrm{SD}))$ & $78.3(12.4)$ & $82.1(13.8)$ & $74.6(9.6)$ & 0.001 \\
HC $(\mathrm{cm})(\mu(\mathrm{SD}))$ & $97.1(9.2)$ & $97.2(9.8)$ & $96.9(8.7)$ & 0.865 \\
WHR $(\mu(\mathrm{SD}))$ & $0.80(0.07)$ & $0.84(0.07)$ & $0.77(0.05)$ & $<0.001$ \\
Apple-shaped ${ }^{\mathrm{a}}(\mathrm{n}(\%))$ & $25(16.7 \%)$ & $11(14.9 \%)$ & $14(18.4 \%)$ & 0.715 \\
Pear-shaped $(\mathrm{n}(\%))$ & $48(32 \%)$ & $27(36.5 \%)$ & $21(27.6 \%)$ & 0.324 \\
FBG $(\mathrm{mg} / \mathrm{dl})(\mu(\mathrm{SD}))$ & $87.8(7.3)$ & $88.1(7.5)$ & $87.5(7.3)$ & 0.600 \\
FBG $\geq 100 \mathrm{mg} / \mathrm{dl}(\mathrm{n}(\%))$ & $9(6 \%)$ & $4(5.4 \%)$ & $5(6.6 \%)$ & 1 \\
\hline
\end{tabular}

BMI: body mass index, WC: waist circumference, HC: hip circumference, WHR: waist-hip ratio, FBG: fasting blood glucose. ${ }^{\mathrm{a} B M I} \geq 23 \mathrm{~kg} / \mathrm{m}^{2}$, WHR $>0.90$ for male and $>0.80$ for female. ${ }^{\mathrm{b}} \mathrm{BMI} \geq 23 \mathrm{~kg} / \mathrm{m}^{2}$, WHR $<0.90$ for male and $<$ 0.80 for female.

Table 2. Pearson's correlation coefficients (r) of BMI with WHR

\begin{tabular}{lll}
\hline Subject & $r$ value & $p$ value \\
\hline Overall (Males \& Females) & 0.617 & $<0.001$ \\
Male & 0.777 & $<0.001$ \\
Female & 0.54 & $<0.001$ \\
\hline
\end{tabular}

BMI: body mass index, WHR: waist-hip ratio

Table 3. Pearson's correlation coefficients (r) of FBG with BMI and WHR

\begin{tabular}{lll}
\hline \multirow{2}{*}{ Subject } & \multicolumn{2}{l}{ FBG } \\
\cline { 2 - 3 } & BMI & WHR \\
\hline Overall (Males \& & & \\
Females) & 0.217 & 0.210 \\
$r$ value & 0.008 & 0.010 \\
$p$ value & & \\
\hline Male & & \\
$r$ value & 0.226 & 0.232 \\
$p$ value & 0.053 & 0.046 \\
\hline Female & & \\
$r$ value & 0.203 & 0.207 \\
$p$ value & 0.079 & 0.072 \\
\hline BMI: & &
\end{tabular}

BMI: body mass index, WHR: waist-hip ratio, FBG: fasting blood glucose

\section{DISCUSSION}

From this study we found the overweight and obesity have becoming a common issue either in male or in female students. The prevalence is higher when compared to the previous study conducted in Indonesia in 2014-2015 (34.3\%) (Pengpid \& Peltzer 2017), and to other studies in Pakistan (31.1\%), Thailand (20.8\%) and Bangladesh (20\%) (Khan et al 2016, Pengpid \& Peltzer 2015, Howlader et al 2018). In our study, the prevalence of the obesity was slightly higher in males compared to in females. This might be due to the genetics and/ or environment, such as restrictive diet life style amongst females is arguably more popular to stay slim (Khan et al 2016, Chao et al 2012, Al-Kilani et al 2012). The BMI and WHR differences were found between genders; from both we could determine the fat deposition pattern in the body (Fu et al 2015, WHO 2000, WHO 2011). In male students, the pear-shaped obesity was more commonly found than in females. On the other hand, the apple-shaped obesity was more common amongst females, which indicates the central type obesity that has been reported to a higher risk to develop the cardiovascular disease than those with pearshaped (Gadekar et al 2018, Fu et al 2015, WHO 2000). Apple-shaped obesity is considered more dangerous than pear-shaped obesity because of the accumulation of fat in the deep abdominal area around the visceral organs that can lead to the development of arterial hypertension and insulin resistance which may lead to the heart diseases, dyslipidemia and T2DM in later life (Gadekar et al 2018, Klop et al 2013, Rolland et al 2007).

We found that students with higher BMI, or WHR, would have significant positive correlation to the higher FBG $(>=100 \mathrm{mg} / \mathrm{dl})$. This showed an indication of an impaired fasting glucose, a condition which might lead to the prediabetes if it was not well managed. Higher FBG levels were more common in females than in males. The prevalence of high FBG found in the current study was higher to the previous study in Eastern China due to the difference in the study methodology and sampling (Hao et al 2014, Somers et al 2006, Huang et al 2004). However, in Bangladesh and South Africa, there were no significant correlations between the FBG and the BMI amongst the university students (Howlader et al 2018, Yang et al 2002). Students with higher BMI 
tend to have higher WHR; an elevated free fatty acid inflow to the liver tend to occur, and generated the abdominal adiposity. This would contribute to the insulin sensitivity impairment through the secretion of adipokines that might impair the glucose tolerance (Gadekar et al 2018, Klop et al 2013). Furthermore, the adiponectin is lower in the obese patients; a condition that might give some degree of higher risks to develop T2DM. Adiponectin was another type of adipokines which could improve the insulin secretion and sensitivity also the fatty acid oxidation to prevent the atherosclerosis and T2DM by decreasing the inflammatory process (Somers et al 2006, Huang et al 2004, Yang et al 2002).

\section{CONCLUSION}

This study has resulted that male students had significantly higher BMI and WHR than the female students. Higher FBG was significantly observed in students with higher BMI and/ or WHR.

\section{REFERENCES}

ADA (2005). Diagnosis and classification of diabetes mellitus. Diabetes Care 28, S37-42.

Al-Kilani H, Waly M, Yousef R (2012). Trends of obesity and overweight among college students in Oman: a cross sectional study. Sultan Qaboos Univ Med J 12, 69-76.

Chao CY, Shih CC, Wang CJ, Wu JS, Lu FH, Chang CJ, et al (2012). Low socioeconomic status may increase the risk of central obesity in incoming university students in Taiwan. Obes Res Clin Pract 8, e212-219.

Doustjalal SR, Gujjar KR, Sharma R, Nurfatiha M, Firzanah RN, Syukri MKM, et al (2016). Correlation between body mass index (BMI) and waist to hip ratio (WHR) among undergraduate students. Pak Journal of Nutr 15, 618-624.

Fu J, Hofker M, Wijmenga C (2015). Apple or pear: size and shape matter. Cell Metab 21, 507-508.

Gadekar T, Dudeja P, Basu I, Vashisht S, Mukherji S (2018). Correlation of visceral body fat with waist-hip ratio, waist circumference and body mass index in healthy adults: a cross sectional study. Med J Armed Forces India. Available from: https://doi.org/10.1016/j.mjafi. 2017.12.001. Accessed May 25, 2019.

Hao C, Zhang C, Chen W, Shi Z (2014). Prevalence and risk factors of diabetes and impaired fasting glucose among university applicants in Eastern China: findings from a population-based study. Diabet Med 31, 1194-1198.
Howlader MH, Islam AM, Rahman MM, Mili US, Nur RS, Kibria MG (2018). Correlation between body mass index and fasting blood glucose level in a selected group of teenagers in Bangladesh. Medicine Today 30, 74-77.

Huang KC, Lue BH, Yen RF, Shen CG, Ho SR, Tai TY, et al (2004). Plasma adiponectin levels and metabolic factors in nondiabetic adolescents. Obes Res 12, 119124.

Khan ZN, Assir MZ, Shafiq M, Chaudhary AE, Jabeen A (2016). High prevalence of preobesity and obesity among medical students of Lahore and its relation with dietary habits and physical activity. Indian $\mathbf{J}$ Endocrinol Metab 20, 206-210.

Klop B, Elte J, Cabezas M (2013). Dyslipidemia in obesity: mechanisms and potential targets. Nutrients 5, 1218-1240.

Mehdad S, Hamrani A, El Kari K, El Hamdouchi A, Barakat A, El Mzibri M, et al (2012). Body mass index, waist circumference, body fat, fasting blood glucose in a sample of Moroccan adolescents aged 11-17 years. J Nutr Metab 2012, 510458.

Mishra S, Behera A, Behera B, Dash S (2014). Effect of body mass index on gender difference in lung functions in Indian population. Int J Clin Exp Physiol 1, 229-231.

Pengpid S, Peltzer K (2015). Prevalence of overweight and underweight and its associated factors among male and female university students in Thailand. HOMO 66, 176-186.

Pengpid S, Peltzer K (2017). The prevalence of underweight, overweight/obesity and their related lifestyle factors in Indonesia, 2014-2015. AIMS Public Health 4, 633-649.

PERKENI (2015). Konsensus pengelolaan dan pencegahan diabetes mellitus tipe 2 di Indonesia 2015. Jakarta, Pengurus Besar Perkumpulan Endokrinologi Indonesia, p 12-13.

Poobalan A, Aucott L (2016). Obesity among young adults in developing countries: a systematic overview. Curr Obes Rep 5, 2-13.

Portero McLellan KC, Wyne K, Villagomez ET, Hsueh WA (2014). Therapeutic interventions to reduce the risk of progression from prediabetes to type 2 diabetes mellitus. Ther Clin Risk Manag 10, 173-188.

Rolland YM, Haren MT, Patrick P, Banks WA, Malmstrom TK, Miller DK, et al (2007). Adiponectin levels in obese and non-obese middle-aged AfricanAmerican women. Obes Res Clin Pract 1, 27-37

Somers A, Rusford E, Hassan M, Erasmus R (2006). Screening for diabetes mellitus in learners residing in the Belhar, Delft and Mfuleni communities of Cape Town, Western Cape, South Africa. S Afr Fam Pract 48, 16-16d 
Stroud C, Walker LR, Davis M, Irwin CE (2015). Investing in the Health and Well-Being of Young Adults. J Adolesc Health 56, 127-129.

WHO (2000). The Asia-Pacific perspective: redefining obesity and its treatment. Sydney, Health Communication. Available from: http//www.wpro.who.int/nutrition/documents/

docs/Redefiningobesity.pdf. Accessed May 26, 2019.
WHO (2011). Waist circumference and waist-hip ratio: report of a WHO expert consultation, Geneva 8-11 December 2008. Geneva, WHO Document Production Services, Available

from: http://whqlibdoc.who.int/publications/2011/97892415 01491_eng.pdf. Accessed May 26, 2019.

Yang WS, Lee WJ, Funahashi T, Tanaka S, Matsuzawa Y, Chao CL, et al (2002). Plasma adiponectin levels in overweight and obese asians. Obes Res 10, 11041110. 